\title{
Pengaruh Kombinasi Starter Bakteri Asam Laktat (BAL) pada Pembuatan Keju Kedelai (Soy Cheese)
}

\author{
Ayu Arsyi Anggraini ${ }^{1)}$, Tri Ardyati ${ }^{2)}$ \\ 1), 2) Jurusan Biologi, Fakultas Matematika dan Ilmu Pengetahuan Alam, Universitas Brawijaya, Malang \\ Alamat korespondensi : ${ }^{1)}$ ayuarsyianggraini@gmail.com, ${ }^{2)}$ tri ardyati@yahoo.com
}

\begin{abstract}
ABSTRAK
Bahan dasar keju yaitu susu sapi yang menganduk lemak yang tinggi, sehingga tidak dapat dikonsumsi seseorang yang sedang diet. Susu kedelai sebagai bahan dasar alternatif dalam pembuatan keju belum banyak dilakukan di Indonesia. Penelitian ini bertujuan untuk mengetahui karakterisitik sel BAL dan organoleptik keju kedelai. Rancangan penelitian yang digunakan adalah Rancangan Acak Lengkap (RAL) dengan faktor kombinasi BAL yaitu L. bulgaricus : S. thermophillus (1:1). Tahapan yang dilakukan meliputi karaketrisasi sel BAL, pembuatan soy cheese dan uji organoleptik. Lactobacillus bulgaricus dan Streptococcus thermophillus memiliki hasil pewarnaan Gram positif. Berdasarkan hasil uji organoleptic, soy cheese dengan dua kombinasi BAL dapat diterima oleh responden $(63,75 \%)$.
\end{abstract}

Kata kunci: bakteri asam laktat, organoleptik, soy cheese

\section{ABSTRACT}

Cheese is made from cow's milk, it can't be consumed for a diet. The utilization of soy milk as a raw material for cheese was not developing in Indonesia. The objectives of this study are to determine characteristic and organoleptic assay of soy cheese. This study used Completely Randomized Design with LAB combination Lactobacillus bulgaricus and Streptococcus thermophillus (1:1). Steps of this research are LAB cell characterization, soy cheese production, organoleptic assay. Lactobacillus bulgaricus and Streptococcus thermophillus is Gram positive. Soy cheese can be accepted respondent (63.75\%).

Key words: Lactic Acid Bacteria, organoleptic, soy cheese

\section{PENDAHULUAN}

Probiotik merupakan mikroba hidup yang dapat hidup atau berkembang dalam usus dan dapat menguntungkan inangnya baik secara langsung maupun tidak langsung melalui hasil metabolitnya [1]. Probiotik dapat berupa bakteri, jamur atau ragi [2]. Tidak semua bakteri baik dapat dijadikan sebagai probiotik, salah satu bakteri yang berperan sebagai probiotik adalah bakteri asam laktat (BAL). Bakteri probiotik umumnya hidup di dalam saluran pencernaan dan bersifat mutualisme dengan inangnya, dapat hidup pada kisaran $\mathrm{pH} 2-4$, tidak menyebabkan dampak yang negatif pada tubuh, tidak patogen, tidak membentuk spora, aerob dan anaerob, tidak mengganggu ekosistem tubuh dan dapat hidup di dalam usus [3].

Keju produksi Indonesia biasanya dibuat dari susu sapi dengan penggumpalnya menggunakan rennet lambung anak sapi. Susu sapi sebagai bahan dasar keju masih mengandung lemak yang tinggi, sehingga tidak dapat dikonsumsi oleh seseorang yang sedang menjalani diet. Alternatif yang dapat digunakan yaitu mengganti susu sapi dengan susu kedelai [4].

Kedelai memiliki kandungan nutrisi terlengkap terutama protein yang berupa essensial maupun non essensial dan menjadi sumber gizi utama yang berupa protein nabati. [5]. Kedelai memiliki memiliki manfaat untuk mencegah penyakit kanker maupun osteoporosis. Kedelai memiliki kandungan kandungan karbohidrat berupa oligosakarida rafinosa dan stakiosa yang sulit dicerna oleh manusia. Salah satu cara untuk memecah karbohidrat tersebut menjadi gula sederhana sebelum dikonsumsi yaitu dengan menambahkan kultur bakteri asam laktat (BAL) [6].

Konsumsi probiotik dalam makanan merupakan cara yang baik untuk menghidupkan kembali keseimbangan mikroflora usus. Inokulum BAL sering digunakan untuk pembuatan keju dengan bahan dasar susu sapi, sedangkan untuk bahan dasar susu kedelai masih jarang terutama yang menggunakan berbagai 
macam kombinasi BAL [4]. Penelitian ini bertujuan untuk mengetahui pengaruh kombinasi bakteri asam laktat pada soy cheese.

\section{METODE PENELITIAN}

Rancangan Penelitian. Rancangan penelitian menggunakan Rancangan Acak Kelompok (RAL) dengan tiga kali pengulangan. Kombinasi BAL yang digunakan yaitu Lactobacillus bulgaricus dan Streptococcus thermophillus (1: 1).

Karakterisasi sel BAL. Karakter bakteri yang diamati meliputi bentuk sel dan Gram. Isolat diambil satu ose, kemudian diletakkan pada slide glass yang telah berisi 1-2 ose akuades steril. Slide glass dilewatkan di atas api. Preparat digenangi dengan gram A (Crystal violet) selama 1 menit. Gram B (Iodin) selama 1 menit. Gram C (Alkohol $90 \%$ selama 30 detik. Gram D (Safranin) selama 1 menit dan sisa cat dibuang lalu preparat dikeringkan anginkan. Preparat diamati dengan mikroskop perbesaran 1000x.

Pembuatan soy cheese. Susu kedelai sebelumnya dipasteurisasi pada suhu $80{ }^{\circ} \mathrm{C}$ selama 15 menit, lalu didinginkan hingga suhu mencapai $\pm 40{ }^{\circ} \mathrm{C}$ [7]. Kemudian, ditambahkan kultur sebanyak $10 \%$ dan diinkubasi di dalam inkubator pada suhu $37{ }^{\circ} \mathrm{C}$ selama 24 jam. Curd yang telah terbentuk dicuci dengan menambahkan air suhu $72{ }^{\circ} \mathrm{C}$ selama 15 menit. Dipisahkan antara curd dan whey sampai habis. Curd dicetak dan dipress selama 3 jam, kemudian direndam dalam air garam dengan konsentrasi $2 \%$ selama 1 jam dan diperam dalam kulkas suhu $10-15{ }^{\circ} \mathrm{C}[8]$.

Uji organoleptik. Uji organoleptik pada penelitian ini menggunakan 20 orang responden. Parameter yang di uji antara lain warna, aroma, rasa dan tekstur.

\section{HASIL DAN PEMBAHASAN}

Karekterisasi sel BAL. Bakteri asam laktat memiliki karakterisitik Gram positif pada pewarnaan Gram. Gambar 1. merupakan hasil pewarnaan Gram dari masing-masing isolat.

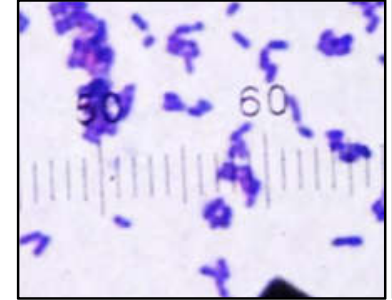

(a)

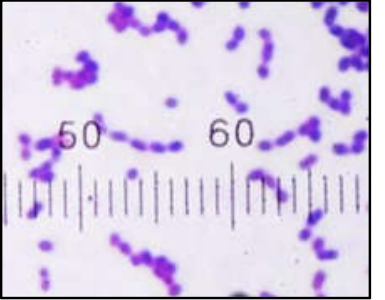

(b)
Gambar 1. Perwarnaan Gram, (a). Lactobacillus bulgaricus dan (b) Streptococcus thermophillus (1000x)

Lactobacillus bulgaricus berbentuk basil, sedangkan Streptococcus thermophillus berbentuk coccus. Hal tersebut sesuai dengan ciri bakteri asam laktat yang memiliki Gram positif [9]. Warna ungu tersebut terjadi karena dinding sel bakteri mengikat cat kristal violet (Gram A) yang diperkuat oleh iodin (Gram B) dan kristal violet tersebut tidak akan hilang pada waktu diberi cat peluntur (Gram C), sehingga tidak terpengaruh pada saat diberi Gram D yang berwarna merah.

Lactobacillus bulgaricus sering digunakan sebagai starter dalam pembuatan yoghurt. Bakteri ini memiliki ukuran 0,5-1,2 x 1-10 $\mu \mathrm{m}$, merupakan bakteri Gram positif, berbentuk batang, fakultatif anaerob, tidak berspora, termasuk bakteri mesofilik, suhu optimum untuk tumbuh 34-45 ${ }^{\circ} \mathrm{C}, \quad \mathrm{pH}$ 4-5,5, tergolong homofermentatif karena hanya mampu menghasilkan asam laktat dari fermentasi glukosa. Aktivitas enzim proteolitiknya lebih tinggi dibandingkan dengan bakteri asam laktat lainnya, sehingga produk fermentasi oleh bakteri ini memiliki cita rasa dan nilai gizi yang tinggi [10].

Streptococcus thermophillus merupakan bakteri asam laktat yang berbentuk bulat dan membentuk rantai, tergolong homofermentatif yaitu pada proses fermentasinya menghasilkan lebih dari $85 \%$ asam laktat, suhu optimum pertumbuhannya $37-42^{\circ} \mathrm{C}$, pH optimum 6,5 dan tidak dapat tumbuh pada $\mathrm{pH} 10$, tidak tahan pada konsentrasi garam. Streptococcus thermophillus ini dapat digunakan untuk menghasilkan asam laktat yang digunakan sebagai koagulan dalam menggumpalkan protein susu kedelai [11].

Uji organoleptik. Sebanyak $63,75 \%$ responden menyukai karakter soy cheese. Warna soy cheese yang dihasilkan yaitu putih kekuningkuningan. Rasa soy cheese hampir mirip dengan keju pada umumnya namun masih memiliki rasa 
kedelai. Tekstur yang dihasilkan yaitu lembut dan agak lunak. Hal ini disebabkan karena kedelai memiliki kandungan lemak yang rendah, sehingga tekstur yang dihasilkan tidak terlalu kompak.

\section{KESIMPULAN}

Bakteri asam laktat memiliki karekteristik Gram positif. Penggunaan susu kedelai sebagai bahan dasar dalam pembuatan keju memungkinkan untuk dikembangkan di Indonesia, karena dapat diterima oleh responden dan cukup disukai dengan nilai $(63,75 \%)$.

\section{UCAPAN TERIMA KASIH}

Terima kasih kepada Dr. Suharjono, M.Si., Dr. Ir. Joni Kusnadi, M.Si., Dra. Nanik D. Rahayu, Ekwan N. Wiratno, S.Si., M.Si, Keluarga besar Laboratorium Mikrobiologi JBUB dan Bpk. Aris.

\section{DAFTAR PUSTAKA}

[1] Kompiang, I P. 2009. Pemanfaatan Mikroorganisme Sebagai Probiotik untuk Meningkatkan Produksi Ternak Unggas di Indonesia. Jurnal Pengembangan Inovasi Pertanian. 2 (3): 177 - 191.

[2] Raja, B.R. dan Kantha D.A. 2011. Market Potential For Probiotic Nutritional Supplements in India. African Journal of Business Management. 5 (14): 5418-5423.

[3] Fuller, R. 1989. A Review Probiotic in Man and Animals. Journal of Applied Bacteriology. 66: 365-378.

[4] Retno, E., U. Yuanti dan N. Sandra. 2005. Pembuatan Keju dari Susu Kacang Hijau dengan Bakteri Lactobacillus bulgaricus. Jurnal Ekuilibrium. 4 (2): 58-63.

[5] Kurniawan, R., W. Sandra dan P. A. Surya. 2007. Pembuatan Keju dari Kedelai (Soycheese) secara Batch Menggunakan Bioreaktor Tangki Berpengaduk. Institut Teknologi Nasional. Bandung.

[6] Liu, D. M., L. Li., X. Q. Yang., S. Z. Liang dan J. S. Wang. 2006. Survivability of Lactobacillus rhamnosus during the Preparation of Soy Cheese. Guangzhou, PR China. Jurnal of Food Technology. Biotechnology. 44 (3): 417-422.

[7] Widowati, S., dan Misgiyarta. 2009. Efektifitas Bakteri Asam Laktat (BAL) dalam Pembuatan Produk Fermentasi Berbasis Protein/Susu Nabati. Balai Penelitian Bioteknologi dan Sumber Daya Genetik Pertanian. Prosiding

[8] Febria, F. A. 2001. Pembuatan Keju ('SOYCHEESE') sebagai Produk Alternatif Pengolahan Kedelai (Glycine max L. Merr.) dengan Menggunakan Bakteri Lactobacillus bulgaricus dan Streptococcus lactis. ITB. Bandung. Thesis.

[9] UNIMED. 2009. Bakteri Asam Laktat. Universitas Negeri Medan. Medan.

[10] Fardiaz, S. 1993. Mikrobiologi Pengolahan Pangan. Departemen Pendidikan dan Kebudayaan Direktorat Jendral Perguruan Tinggi Pusat Antar Universitas Pangan dan Gizi, Institut Pertaniaan Bogor.

[11] Sudarmadji, S., B. Haryono dan Suhardi. 1984. Prosedur Analisa untuk Bahan Makanan dan Pertanian. Liberty. Yogyakarta. 